\title{
Glycosaminoglycans and vitamin C in ovo feeding affects bone characteristics of chicks
}

\author{
Elaine Talita Santos ${ }^{1}$ (D), Sarah Sgavioli ${ }^{*}$ (iD), Diana Maryuri Correa Castiblanco ${ }^{1}$ (iD), Carla \\ Heloísa de Faria Domingues ${ }^{3}$ (iD), Thays Cristina Oliveira de Quadros ${ }^{1}$ (iD, Liliana Longo \\ Borges $^{1}$ (iD, Tiago Goulart Petrolli ${ }^{4}$ (iD, Silvana Martinez Baraldi-Artoni ${ }^{1}$
}

\author{
${ }^{1}$ Universidade Estadual Paulista, Faculdade de Ciências Agrárias e Veterinárias, Jaboticabal, SP, Brasil. \\ 2 Universidade Brasil, Programa de Mestrado em Produção Animal, Descalvado, SP, Brasil. \\ ${ }^{3}$ Universidade Federal da Grande Dourados, Programa de Pós-graduação em Agronegócios, Dourados, MS, Brasil. \\ ${ }^{4}$ Universidade do Oeste de Santa Catarina, Xanxerê, SC, Brasil.
}

\begin{abstract}
Different levels of glycosaminoglycans (chondroitin sulfate and glucosamine sulfate) and vitamin C were injected in ovo to determine whether additive use influences the incubation parameters and bone characteristics of posthatch chicks. Hatchability was not affected by addition of glycosaminoglycans and vitamin $\mathrm{C}$ in ovo. However, chicks that received $4 \mu \mathrm{g}$ additive showed $2.86 \%$ reduction in total mortality when compared with chicks from non-injected eggs. Moreover, tibia area and femur bone mineral density increased in chicks from eggs injected with 2.16 and $6.00 \mu \mathrm{g}$ of additive, respectively. In ovo feeding with glycosaminoglycans and vitamin $\mathrm{C}$ can benefit bone development in embryos and reduce total mortality during the incubation period.
\end{abstract}

Key Words: ascorbic acid, bone mineral density, bone strength, chondroitin, glucosamine

\section{Introduction}

Upon reaching rapid body growth, efficient feed utilization, and maximum breast meat deposition, broilers begin to show disorders in their bone structure, with increased occurrence of angular and torsional deformities, tibial dyschondroplasia, rickets, osteochondrosis, and femoral necrosis (Almeida Paz et al., 2010). Bone deformities and fractures are severe health problems in modern, rapidly growing broilers, because genetic breeding programs aimed at superior performance have not included improvements in bone development (Almeida Paz et al., 2010).

In ovo feeding can be regarded as supplemental nutrition for the embryo and yolk sac (Santos et al., 2010), which may benefit embryo development and quality of posthatch chicks (Uni and Ferket, 2004).

Polysulfated glycosaminoglycans (GAG) such as glucosamine and chondroitin have anti-inflammatory action and are pharmacologically classified as slow-acting

Received: November 21, 2017

Accepted: May 17, 2018

*Corresponding author: sarahsgavioli@yahoo.com.br

Copyright (C) 2018 Sociedade Brasileira de Zootecnia. This is an Open Access article distributed under the terms of the Creative Commons Attribution License (http://creativecommons.org/licenses/by/4.0/), which permits unrestricted use, distribution, and reproduction in any medium, provided the original work is properly cited. symptomatic drugs that reduce the symptoms of bone disorders such as osteoarthritis in humans and some animal species (Brandt et al., 2002). Additionally, they stimulate the synthesis of proteoglycans and collagen, increasing the proliferation of chondrocytes and bone matrix biosynthesis (Altman et al., 1989; Clark, 1991).

The use of GAG to minimize locomotor issues has been studied in several species, including human (Reginster et al., 2001; Simonaro et al., 2008), bovine (De Mattei et al., 2002), equine (Hanson et al., 1997; Fenton et al., 2000), and canine (Altman et al., 1989; Gonçalves et al., 2008; Melo et al., 2008; Eleotério et al., 2012). However, no research has been published regarding the use of GAG in ovo feeding or in the diet of broilers and laying hens.

Vitamin C, or ascorbic acid, participates in several biological processes. It helps in collagen synthesis and maintenance, is essential for the formation and maintenance of connective tissue, bone, and cartilage, and stimulates the immune system, increasing disease resistance (Berzina et al., 2013; Sgavioli et al., 2013; Chand et al., 2014).

Considering the existing research results about the benefits of vitamin $\mathrm{C}$ supplementation in broilers and chondroitin and glucosamine sulfates in other animal species, this study was conducted to evaluate the use of GAG and vitamin $\mathrm{C}$ in ovo feeding on bone system of developing posthatch chicks. 


\section{Material and Methods}

This study was approved by the local Committee of Ethics in Animal Use (case no. 011424/13) in Jaboticabal, SP, Brazil $\left(21^{\circ} 14^{\prime} 05^{\prime \prime}\right.$ South latitude and 48 $17^{\prime} 09^{\prime \prime}$ West longitude, and average altitude of $615.01 \mathrm{~m}$ ).

Four hundred and ninety (490) fertile eggs from 47-week-old Cobb $^{\circledR} 500$ broiler hens were distributed $(67 \pm 1.16 \mathrm{~g})$ into 14 trays (replicates) at seven eggs/ treatment/tray (98 eggs/treatment). Eggs were incubated in incubators $\left(\mathrm{CASP}^{\circledR}\right.$, IHM Line e-V A 06, Amparo, São Paulo, Brazil) equipped with automatic temperature, humidity, and egg-turning control. The initial and final temperatures and humidity were 37.8 and $36.9{ }^{\circ} \mathrm{C}$ and 85.7 and $84.0 \%$, respectively, with $504 \mathrm{~h}$ of incubation.

Eggs were distributed into five treatments, in a completely randomized experimental design, as follows: eggs non-injected (unperforated) and eggs injected with 0 , 2,4 , or $6 \mu \mathrm{g}$ additive $/ 100 \mu \mathrm{L}$ water on the fourth day of incubation.

According to Shim and Pesti (2011), in broiler embryos, the bone system starts to develop on the fourth day of incubation; for this reason, this date was chosen. Each $100 \mathrm{~g}$ of additive contained $30 \mathrm{~g}$ chondroitin sulfate, $30 \mathrm{~g}$ glucosamine, $5 \mathrm{~g}$ vitamin $\mathrm{C}$ (Synth, 99\% purity, Diadema, Brazil), and $100 \mathrm{~g}$ excipient q.s. The chondroitin sulfate $\left[\left(\mathrm{C}_{14} \mathrm{H}_{21} \mathrm{NO}_{14} \mathrm{~S}\right) n\right.$, Infiniti Nutraceuticals, Inc.] had a purity of $91.35 \%$, and the potassium glucosamine sulfate $\left[\left(\mathrm{C}_{6} \mathrm{H}_{14} \mathrm{NO}_{5}\right)_{2} \mathrm{SO}_{4} \times 2 \mathrm{KCl}\right.$, Zheijiang Freemen Inc. $]$ had a sulfate content of $15.7 \%$.

Each inoculated egg received the following constituents for the respective treatments: $2 \mu \mathrm{g}$ of additive $-0.6 \mu \mathrm{g}$ of chondroitin sulfate $+0.6 \mu \mathrm{g}$ of glucosamine sulfate $+0.1 \mu \mathrm{g}$ of vitamin $\mathrm{C} ; 4 \mu \mathrm{g}$ additive $-1.2 \mu \mathrm{g}$ of chondroitin sulfate $+1.2 \mu \mathrm{g}$ of glucosamine sulfate $+0.2 \mu \mathrm{g}$ of vitamin $\mathrm{C}$; and $6 \mu \mathrm{g}$ additive $-1.8 \mu \mathrm{g}$ of chondroitin sulfate $+1.8 \mu \mathrm{g}$ of glucosamine sulfate $+0.4 \mu \mathrm{g}$ of vitamin $\mathrm{C}$.

The formulation of the additive injected in ovo was based on the veterinary medicine Condrodoton $500 \mu \mathrm{g}$ (Vetnil ${ }^{\circledR}$, Louveira, São Paulo, Brazil), recommended for dogs. The supplied quantity of chondroitin sulfate, glucosamine sulfate, and vitamin $\mathrm{C}$ in micrograms were thus converted according to the dog weight in pounds to the quantity in micrograms of those substances for broiler weight in pounds. Results of studies on broiler nutrition (Ferreira et al., 2015; Sgavioli et al., 2017) were also used to adjust the glucosamine and chondroitin doses in the additive injected.

For the additive injection, the eggs were held horizontally and, after cleaning with $70 \%$ ethanol, the shell was perforated near the thin end (the end opposite to the air cell) with a sterile needle [Injex, $13 \times 0.38(27.5$ G1/2")] through which $100 \mu \mathrm{L}$ aqueous additive solution were injected into the albumen, approximately $6 \mathrm{~mm}$ below the membrane. The solution was prepared with ultra-pure water autoclaved in the dark because of its photosensitivity (Sgavioli et al., 2013). After injection, the hole was sealed with a label identifying the treatment and replicate.

Hatchability (number of hatched chicks/number of incubated fertile eggs) and embryo mortality were determined according to embryo diagnosis phases (initial: 1-7 days; intermediate: 8-14 days; and late: 15-21 days of incubation, respectively).

The relative weight (\%) of chicks post-hatch was obtained as the absolute weight of the chick (g) relative to the egg weight (g) (at day 0 of incubation).

Egg mass loss was calculated as the difference in egg weight before incubation and weight at the 18th day of incubation, expressed as a percentage of initial egg weight. Eggshell conductance was calculated as egg mass loss (g) divided by steam saturation pressure $(23.86 \mathrm{~mm} / \mathrm{Hg}$ at $25^{\circ} \mathrm{C}$ ).

Eight birds per treatment whose average body weight was close to the average weight of the experimental unit were sacrificed at one day of age, in a total of 40 animals. Birds were stunned by individual exposure to $\mathrm{CO}_{2}$ gas for 2 min in a flow-through system and then slaughtered by cervical dislocation.

Bone mineral density (BMD) $\left(\mathrm{g} / \mathrm{cm}^{2}\right)$, area $\left(\mathrm{cm}^{2}\right)$, and length were determined in the left femur and tibia using dual-energy X-ray absorptiometry (Horizon Discovery Dxa Hologic $^{\circledR}$, Massachusetts, USA). Prior to sample scanning, the device was calibrated with a phantom, supplied by the manufacturer (Hologic ${ }^{\circledR}$, Massachusetts, USA), as bones. For all analyses, a small-animal software (Hologic ${ }^{\circledR}$, Massachusetts, USA) was used. Clean bones were placed with the cranial face in contact with an acrylic container with deionized water and scanned using a densitometer. The small-animal software was used to select the region for subsequent densitometric analysis. After the densitometric analysis, the bone length was assessed using a digital micrometer (MDC-Lite, $0.001 \mathrm{~mm}$ resolution, Mitutoyo, Suzano, SP, Brazil).

Left femur and tibia were used for the mechanical bone-strength tests (three-point bending). The tests were conducted using an EMIC $^{\circledR}$ (DL 3000) universal testing machine. The load was applied at a rate of $5 \mathrm{~mm} / \mathrm{min}$ with a force of $2000 \mathrm{~N}$ to determine the maximum permissible force (Fmax) of the bone and the deformation (bend) caused by Fmax. Bones were fixed on two supports (two points), 
with span adjusted according to the size of the smallest bone. The force was then applied at the geometric mean point of the bones between the two supports (the middle third of the bone), and the equipment recorded the results. These variables express bone strength at the ends and in the middle third of the bone.

Right femur and tibia were used to determine bone calcium, phosphorus, and ash contents. The soft tissue was removed, and bones were boiled in deionized water for $5 \mathrm{~min}$. After drying at room temperature, samples were immersed in petroleum ether for $48 \mathrm{~h}$, dried in a forcedventilation oven at $60{ }^{\circ} \mathrm{C}$ for $48 \mathrm{~h}$, and then ground in a ball mill. Bone mineral content was determined using wet analyses. Ash content was determined by burning the samples at $600^{\circ} \mathrm{C}$. The methods were applied according to Silva and Queiroz (2002) and expressed as a percentage of defatted dry matter or mineral matter.

The effects of incubation treatments (eggs non-injected and injected with $0,2,4$, or $6 \mu$ g additive) on all studied parameters were analyzed statistically using the model described below:

$$
Y i j=\mu+T i+e i j,
$$

in which $\mathrm{Y}=$ studied parameter; $\mu=$ mean value of the parameter; $\mathrm{Ti}=$ treatment $(0,2,4$, or $6 \mu \mathrm{g}$ additive $)$; and eij $=$ residual error.

Data were subjected to analysis of variance by the General Linear Model procedure (GLM) of $\mathrm{SAS}^{\circledR}$ (Statistical Analysis System, version 9.2) and analyzed for the presence of outliers (Box-and-Whisker plot), normal distribution of studentized errors (Cramer-Von-Mises test), and homogeneity of variances (Brown-Forsythe) (Littell et al., 2006).

Means were compared by $5 \%$ probability polynomial orthogonal contrasts, as follows: contrast 1 - comparison between the non-injected egg treatment versus the average of treatments with $0,2,4$, and $6 \mu \mathrm{g}$ of additives injected; contrasts 2 and 3 - comparisons using linear and quadratic regression models $(0,2,4$, and $6 \mu \mathrm{g}$ of additive) (Robbins et al., 1979) to check the effects of additive application.

For embryonic mortality, data were analyzed for frequency by Fisher's exact test at the 5\% probability level.

\section{Results}

Hatchability, egg mass loss, conductance, chick relative weight (Table 1), and embryonic mortality (Table 2) did not differ based on the analyzed contrasts $(\mathrm{P}>0.05)$.

In the embryo diagnosis, there was an effect for intermediate $(\mathrm{P}=0.0083)$, late $(\mathrm{P}=0.0083)$, or total $(\mathrm{P}=0.0167)$ mortality, with the lowest mortality found in the treatments injected with 0,2 , and $4 \mu \mathrm{g}$ additive, respectively (Table 2 ).

Tibial area and femur bone mineral density (BMD) responded quadratically $(\mathrm{P}=0.0315$ and $\mathrm{P}=0.0333$, respectively) (Table 3). According to equations Area tibia $=$ 0.0038 additive $^{2}-0.0195$ additive $+0.511\left(\mathrm{R}^{2}=0.98\right)$ and $\mathrm{BMD}_{\text {femur }}=-0.0003$ additive ${ }^{2}+0.0013$ additive +0.0196 $\left(\mathrm{R}^{2}=0.60\right)$, additive injections of 6 and $2.16 \mu \mathrm{g}$ increase the tibial area and femur BMD, respectively.

There was a contrast-1 effect (non-injected eggs vs. injected eggs) for the femur area $(\mathrm{P}=0.0175)$. Smaller femur areas were observed in injected eggs $\left(0.37 \mathrm{~cm}^{2}\right)$ when compared with non-injected eggs $\left(0.40 \mathrm{~cm}^{2}\right)$ (Table 3$)$.

Table 1 - Glycosaminoglycans (chondroitin sulfate + glucosamine sulfate) and vitamin $\mathrm{C}$ in ovo feeding on hatchability, egg mass loss, eggshell conductance, and relative chick weight

\begin{tabular}{|c|c|c|c|c|}
\hline Treatment & $\begin{array}{c}\text { Hatchability } \\
(\%)\end{array}$ & $\begin{array}{l}\text { Egg mass } \\
\operatorname{loss}^{2}(\%)\end{array}$ & $\begin{array}{l}\text { Eggshell } \\
\text { conductance }\end{array}$ & $\begin{array}{c}\text { Relative } \\
\text { chick } \\
\text { weight }^{3}(\%)\end{array}$ \\
\hline Non-injected eggs & 84.29 & 11.08 & 0.464 & 73.73 \\
\hline $0 \mu \mathrm{g}$ of additive & 84.76 & 10.91 & 0.457 & 73.81 \\
\hline $2 \mu \mathrm{g}$ of additive ${ }^{1}$ & 83.81 & 10.25 & 0.429 & 72.69 \\
\hline $4 \mu \mathrm{g}$ of additive & 87.14 & 10.33 & 0.432 & 72.74 \\
\hline $6 \mu \mathrm{g}$ of additive & 83.81 & 10.42 & 0.437 & 72.79 \\
\hline SEM & 1.76 & 0.17 & 0.01 & 0.34 \\
\hline \multirow[t]{2}{*}{ CV (\%) } & 18.42 & 18.73 & 18.74 & 2.84 \\
\hline & \multicolumn{4}{|c|}{ Contrast probability } \\
\hline $\begin{array}{l}\text { Non-injected vs. } \\
\text { injected eggs }\end{array}$ & 0.8953 & 0.1691 & 0.1688 & 0.4544 \\
\hline Linear effect ${ }^{4}$ & 0.9792 & 0.3988 & 0.3968 & 0.4539 \\
\hline Quadratic effect ${ }^{4}$ & 0.7687 & 0.3031 & 0.3011 & 0.5063 \\
\hline
\end{tabular}

SEM - standard error of the mean; CV - coefficient of variation.

${ }^{1}$ Additive composition: each $100 \mathrm{mg}$ of additive contained $30 \mathrm{mg}$ of chondroitin sulfate, $30 \mathrm{mg}$ of glucosamine, and $5 \mathrm{mg}$ of vitamin C (excipient q.s. $-100 \mathrm{~g}$ ). Probability: $\mathrm{P}>0.05$

${ }^{2}$ Egg mass loss: difference in egg weight before incubation and at the 18 th day of incubation, expressed as a percentage of initial egg weight.

${ }^{3}$ Relative weight: absolute weight (g) of the chicks relative to egg weight (g) (at day 0 of incubation)

${ }^{4}$ Treatments used for the regression calculation: $0,2,4$, and $6 \mu \mathrm{g}$ of additive.

Table 2 - Glycosaminoglycans (chondroitin sulfate + glucosamine sulfate) and vitamin $\mathrm{C}$ in ovo feeding on embryonic mortality frequency (initial, intermediate, and late)

\begin{tabular}{lcccc}
\hline Treatment & Initial & Intermediate & Late & Total \\
& $(0-7$ days $)$ & $(8-14$ days $)$ & $(15-21$ days $)$ & $(0-21$ days $)$ \\
\hline & \multicolumn{5}{c}{$\%$} \\
Non-injected eggs & 0.00 & 2.62 & 13.10 & 15.72 \\
$0 \mu$ g of additive $^{-1}$ & 3.05 & 1.52 & 10.67 & 15.24 \\
$2 \mu$ g of additive $^{1}$ & 3.47 & 3.47 & 9.25 & 16.19 \\
$4 \mu$ g of additive & 0.00 & 3.22 & 9.65 & 12.86 \\
$6 \mu$ g of additive & 0.00 & 6.07 & 10.12 & 16.19 \\
Probability & 0.0500 & $0.0083^{2}$ & $0.0083^{2}$ & $0.0167^{2}$
\end{tabular}

${ }^{1}$ Additive composition: each $100 \mathrm{mg}$ of additive contained $30 \mathrm{mg}$ of chondroitin sulfate, $30 \mathrm{mg}$ of glucosamine, and $5 \mathrm{mg}$ of vitamin C (excipient q.s. $-100 \mathrm{~g}$ )

${ }^{2}$ Significant at $\mathrm{P}<0.05$ (Fisher's exact test). 
There was a contrast-1 effect (non-injected eggs vs. injected eggs) for femoral BMD $(\mathrm{P}=0.0296)$, whose highest values were found in injected $\left(0.020 \mathrm{~g} / \mathrm{cm}^{2}\right)$ compared with non-injected eggs $\left(0.017 \mathrm{~g} / \mathrm{cm}^{2}\right)$ (Table 3$)$.

The maximum strength and deformation of the femur did not differ based on the analyzed contrasts $(\mathrm{P}>0.05)$ (Table 4).

Femur and tibia concentration of phosphorus (P) responded linearly $(\mathrm{P}=0.0343$ and $\mathrm{P}=0.0353$, respectively) for all injection levels (Table 5). According to the equations $\mathrm{P}_{\text {tibia }}=-0.112$ additive $+18.271\left(\mathrm{R}^{2}=0.78\right)$ and $\mathrm{P}_{\text {femur }}=-0.106$ additive $+19.358\left(\mathrm{R}^{2}=0.95\right)$, when the additive injection concentration increases, there is a reduction in the phosphorus concentration of the femur and tibia of chicks.

\section{Discussion}

In ovo feeding with chondroitin sulfate, glucosamine sulfate, and vitamin $\mathrm{C}$ was evaluated in terms of ability to promote changes in bone and cartilage development posthatch. Despite the increase in femur and tibia area and femur BMD observed with in ovo feeding (GAG + vitamin C), the phosphorus concentration in the femur and tibia declined as the injected concentrations of in ovo feeding were elevated.

The maximum derivative of equations for tibia area and femur BMD revealed that in ovo feeding with 2.16 and $6 \mu \mathrm{g}$ of additive maximizes the response to the cited characteristics, respectively.

Table 3 - Glycosaminoglycans (chondroitin sulfate + glucosamine sulfate) and vitamin $\mathrm{C}$ in ovo feeding on femur and tibia length, bone area, and bone mineral density (BMD) of posthatch chicks

\begin{tabular}{|c|c|c|c|c|c|c|}
\hline \multirow[b]{2}{*}{ Treatment } & \multicolumn{3}{|c|}{ Femur } & \multicolumn{3}{|c|}{ Tibia } \\
\hline & $\begin{array}{l}\text { Length } \\
(\mathrm{cm})\end{array}$ & $\begin{array}{l}\text { Area } \\
\left(\mathrm{cm}^{2}\right)\end{array}$ & $\begin{array}{l}\text { BMD } \\
\left(\mathrm{g} / \mathrm{cm}^{2}\right)\end{array}$ & $\begin{array}{l}\text { Length } \\
(\mathrm{cm})\end{array}$ & $\begin{array}{l}\text { Area } \\
\left(\mathrm{cm}^{2}\right)\end{array}$ & $\begin{array}{c}\text { BMD } \\
\left(\mathrm{g} / \mathrm{cm}^{2}\right)\end{array}$ \\
\hline Non-injected eggs & 2.04 & 0.40 & 0.017 & 2.99 & 0.49 & 0.023 \\
\hline $0 \mu \mathrm{g}$ of additive & 2.03 & 0.37 & 0.020 & 2.97 & 0.51 & 0.021 \\
\hline $2 \mu \mathrm{g}$ of additive ${ }^{1}$ & 2.09 & 0.37 & 0.020 & 2.97 & 0.49 & 0.023 \\
\hline $4 \mu \mathrm{g}$ of additive & 2.10 & 0.36 & 0.022 & 3.05 & 0.49 & 0.022 \\
\hline $6 \mu \mathrm{g}$ of additive & 2.11 & 0.37 & 0.018 & 3.08 & 0.53 & 0.021 \\
\hline SEM & 0.02 & 0.01 & 0.001 & 0.02 & 0.01 & 0.001 \\
\hline CV (\%) & 4.31 & 5.84 & 11.59 & 3.47 & 7.62 & 20.72 \\
\hline
\end{tabular}

Non-injected vs. injected eggs

$\begin{array}{llllll}0.3374 & 0.0175^{3} & 0.0296^{3} & 0.6248 & 0.5865 & 0.6328\end{array}$

Linear effect ${ }^{2}$

$\begin{array}{llllll}0.1662 & 0.9607 & 0.6325 & 0.0570 & 0.2940 & 0.8109\end{array}$

$\begin{array}{lllllll}\text { Quadratic effect }^{2} & 0.5069 & 0.5261 & 0.0333^{3} & 0.7487 & 0.0315^{3} & 0.5339\end{array}$

SEM - standard error of the mean; CV - coefficient of variation.

${ }^{1}$ Additive composition: each $100 \mathrm{mg}$ of additive contained $30 \mathrm{mg}$ of chondroitin

sulfate, $30 \mathrm{mg}$ of glucosamine, and $5 \mathrm{mg}$ of vitamin C (excipient q.s. $-100 \mathrm{~g}$ ).

${ }^{2}$ Treatments used for the regression calculation: $0,2,4$, and $6 \mu \mathrm{g}$ of additive.

${ }^{3}$ Significant at $\mathrm{P}<0.05$.
Glycosaminoglycans and vitamin $\mathrm{C}$ can influence the formation of long bones, as these substances stimulate the synthesis of the proteoglycans and collagen and are capable of increasing the proliferation of the chondrocytes and biosynthesis of the matrix (Clark, 1991; Sgavioli et al., 2017). They are essential in the endochondral ossification process, responsible for the longitudinal growth of long bones, due to epiphyseal disk calcification (Anderson et al., 2005).

Table 4 - Glycosaminoglycans (chondroitin sulfate + glucosamine sulfate) and vitamin $\mathrm{C}$ in ovo feeding on femur and tibia maximum force and deformation of posthatch chicks

\begin{tabular}{|c|c|c|c|c|}
\hline \multirow[b]{2}{*}{ Treatment } & \multicolumn{2}{|c|}{ Femur } & \multicolumn{2}{|c|}{ Tibia } \\
\hline & $\begin{array}{c}\text { Maximum } \\
\text { force }(\mathrm{N})\end{array}$ & $\begin{array}{l}\text { Deformation } \\
(\mathrm{mm})\end{array}$ & $\begin{array}{c}\text { Maximum } \\
\text { force }(\mathrm{N})\end{array}$ & $\begin{array}{c}\text { Deformation } \\
(\mathrm{mm})\end{array}$ \\
\hline Non-injected eggs & 8.47 & 0.62 & 6.45 & 0.88 \\
\hline $0 \mu \mathrm{g}$ of additive & 7.60 & 0.60 & 5.79 & 1.15 \\
\hline $2 \mu \mathrm{g}$ of additive $^{1}$ & 10.63 & 0.79 & 5.75 & 1.13 \\
\hline $4 \mu \mathrm{g}$ of additive & 8.30 & 0.58 & 5.59 & 1.13 \\
\hline $6 \mu \mathrm{g}$ of additive & 9.34 & 0.66 & 6.06 & 1.47 \\
\hline SEM & 0.39 & 0.03 & 0.24 & 0.07 \\
\hline \multirow[t]{2}{*}{ CV (\%) } & 21.13 & 21.93 & 21.90 & 29.73 \\
\hline & \multicolumn{4}{|c|}{ Contrast probability } \\
\hline $\begin{array}{l}\text { Non-injected vs. } \\
\text { injected eggs }\end{array}$ & 0.6002 & 0.6386 & 0.3178 & 0.0641 \\
\hline Linear effect ${ }^{2}$ & 0.4275 & 0.9008 & 0.8066 & 0.1753 \\
\hline Quadratic effect ${ }^{2}$ & 0.2257 & 0.4068 & 0.6567 & 0.2322 \\
\hline
\end{tabular}

SEM - standard error of the mean; CV - coefficient of variation.

${ }^{1}$ Additive composition: each $100 \mathrm{mg}$ of additive contained $30 \mathrm{mg}$ of chondroitin sulfate, $30 \mathrm{mg}$ of glucosamine, and $5 \mathrm{mg}$ of vitamin C (excipient q.s. $-100 \mathrm{~g}$ ).

${ }^{2}$ Treatments used for the regression calculation: $0,2,4$, and $6 \mu \mathrm{g}$ of additive.

Table 5 - Glycosaminoglycans (chondroitin sulfate + glucosamine sulfate) and vitamin $\mathrm{C}$ in ovo feeding on femur and tibia ashes, calcium, and phosphorus contents of posthatch chicks

\begin{tabular}{|c|c|c|c|c|c|c|}
\hline \multirow[b]{2}{*}{ Treatment } & \multicolumn{3}{|c|}{ Femur } & \multicolumn{3}{|c|}{ Tibia } \\
\hline & $\begin{array}{c}\text { Ash } \\
(\% \mathrm{DM})\end{array}$ & $\begin{array}{c}\mathrm{Ca} \\
(\% \text { Ash })\end{array}$ & $\begin{array}{c}\mathrm{P} \\
(\% \text { Ash })\end{array}$ & $\begin{array}{c}\text { Ash } \\
(\% \mathrm{DM})\end{array}$ & $\begin{array}{c}\mathrm{Ca} \\
(\% \mathrm{Ash})\end{array}$ & $\begin{array}{c}\mathrm{P} \\
(\% \text { Ash })\end{array}$ \\
\hline Non-injected eggs & s 25.12 & 38.13 & 18.97 & 25.57 & 34.61 & 17.77 \\
\hline $0 \mu \mathrm{g}$ of additive & 24.58 & 38.59 & 19.30 & 25.02 & 35.15 & 18.21 \\
\hline $2 \mu \mathrm{g}$ of additive ${ }^{1}$ & 24.80 & 39.59 & 19.22 & 25.76 & 35.74 & 18.03 \\
\hline $4 \mu \mathrm{g}$ of additive & 26.02 & 38.45 & 18.96 & 25.80 & 36.47 & 18.04 \\
\hline $6 \mu \mathrm{g}$ of additive & 24.64 & 37.83 & 18.68 & 24.57 & 34.21 & 17.46 \\
\hline SEM & 0.44 & 0.55 & 0.10 & 0.45 & 0.34 & 0.10 \\
\hline CV (\%) & 9.77 & 8.02 & 2.62 & 9.97 & 4.95 & 2.91 \\
\hline
\end{tabular}

$\begin{array}{lllllll}\text { Non-injected vs. } & 0.9281 & 0.7550 & 0.7841 & 0.8208 & 0.3748 & 0.5168\end{array}$ injected eggs

$\begin{array}{lllllll}\text { Linear effect }^{2} & 0.7684 & 0.5684 & 0.0353^{3} & 0.7884 & 0.5329 & 0.0343^{3}\end{array}$ $\begin{array}{lllllll}\text { Quadratic effect }^{2} & 0.4418 & 0.5375 & 0.6300 & 0.3605 & 0.0638 & 0.3752\end{array}$

DM - dry matter; SEM - standard error of the mean; CV - coefficient of variation. ${ }^{1}$ Additive composition: each $100 \mathrm{mg}$ of additive contained $30 \mathrm{mg}$ of chondroitin sulfate, $30 \mathrm{mg}$ of glucosamine, and $5 \mathrm{mg}$ of vitamin C (excipient q.s. $-100 \mathrm{~g}$ ).

${ }^{2}$ Treatments used for the regression calculation: $0,2,4$, and $6 \mu \mathrm{g}$ of additive.

${ }^{3}$ Significant at $\mathrm{P}<0.05$. 
There are several studies on the effects of in ovo feeding with injection of vitamin C (Ghonim et al., 2009; Mohammed et al., 2011; Nowaczewski et al., 2012) in broilers. However, scientific papers that correlate vitamin C in ovo feeding and bone development in broilers are scarce. Sgavioli et al. (2015) injected $6 \mu \mathrm{g}$ ascorbic acid in ovo before incubation and did not observe beneficial effects on bone development (femur and tibia densitometry, mineral density, and bone strength) of birds at 42 days of age.

Therefore, our hypothesis is that in ovo feeding with GAG may be more effective in promoting bone development of posthatch chicks than vitamin C. However, to confirm this hypothesis, further research should be conducted to evaluate the isolated effects of each additive on the bone development of birds.

Higher phosphorus concentration in the femur and tibia were observed when the eggs were injected with water only; therefore, inclusion of GAG and vitamin $\mathrm{C}$ linearly reduces the concentration of phosphorus in the analyzed bones. A lower percentage of bone phosphorus can influence bone mineralization and affect bone mechanical quality, in broilers. According to Vargas Junior et al. (2004), calcium and phosphorus are the most essential minerals for bone formation, since $98 \%$ of the calcium and $80 \%$ of the phosphorus in the body are found in bones. However, the lower tibia and femur phosphorus mineral composition did not affect the density or bone-strength parameters.

According to Uni and Ferket (2003), high concentrations of solutions can interfere with osmotic equilibrium and affect embryo development. These authors described that the maximum osmolarity of the solution to be injected in ovo is $800 \mathrm{mOsm}$. The solution applied in ovo in the present study has a lower osmolarity than this limit ( $86 \mathrm{mOsm})$.

The lack of treatment effects on initial mortality indicates that in ovo feeding with GAG and vitamin $\mathrm{C}$ at the fourth day of incubation did not result in compromised embryo development. Moreover, positive results for total mortality were obtained with in ovo feeding with $4 \mu \mathrm{g}$ of additive $(2.86 \%$ mortality reduction when compared with the unperforated treatment). This is unprecedented information, because it shows for the first time in the literature that in ovo feeding with GAG and vitamin C can reduce embryo mortality.

However, Sgavioli et al. (2015) reported a decrease in egg hatchability after injecting increasing levels of vitamin $\mathrm{C}$ before incubation. This shows that the effect of in ovo feeding on hatchability varies with the concentration of the solution, stage of embryonic development, and egg region where the solution was injected.
Jochemsen and Jeurissen (2002) asserted that the in ovo injection site can be determined according to egg incubation day. According to Ohta et al. (2001), in ovo injection of products must be performed in the extra embryo cavity or yolk sac at the 7th day of incubation to avoid decreased hatchability and to benefit embryo development.

\section{Conclusions}

In ovo feeding with glycosaminoglycans and vitamin $\mathrm{C}$ can change the bone development of chicks and reduce their mortality. Our research testing in ovo feeding with glycosaminoglycans and vitamin $\mathrm{C}$ has established a new science of neonatal nutrition.

\section{Acknowledgments}

The authors would like to thank the Fundação de Amparo à Pesquisa do Estado de São Paulo (FAPESP, grant no. 2013/04158), for the financial support of this study.

\section{References}

Almeida Paz, I. C. L.; Garcia, R. G.; Bernardi, R.; Nääs, I. A.; Caldara, F. R.; Freitas, L. W.; Seno, L. O.; Ferreira, V. M. O. S.; Pereira, D. F. and Cavichiolo, F. 2010. Selecting appropriate bedding to reduce locomotion problems in broilers. Revista Brasileira de Ciência Avícola 12:189-195. https://doi.org/10.1590/S1516635X2010000300008

Altman, R. D.; Dean, D. D.; Muniz, O. E. and Howell, D. S. 1989. Therapeutic treatment of canine osteoarthritis with glycosaminoglycan polysulfuric acid ester. Arthritis \& Rheumatology 32:759-765. https://doi.org/10.1002/anr.1780321016

Anderson, J. W.; Nicolosi, R. J. and Borzelleca, J. F. 2005. Glucosamine effects in humans: a review of effects on glucose metabolism, side effects, safety considerations and efficacy. Food Chemical and Toxicology 43:187-201. https://doi.org/10.1016/j. fct.2004.11.006

Berzina, N.; Markovs, J.; Dizhbite, T.; Apsite, M.; Vasilyeva, S.; Basova, N.; Smirnova, G. and Isajevs, S. 2013. Oxidative stress and innate immunity status in chickens exposed to high dose of ascorbic acid. Cell Biochemistry Function 31:551-559. https://doi. org/10.1002/cbf.2934

Brandt, K. D.; Mazzuca, S. A.; Conrozier, T.; Dacre, J. E.; Peterfy, C. G.; Provvedini, D.; Ravaud, P.; Taccoen, A. and Vignon, E. 2002. Which is the best radiographic protocol for a clinical trial of a structure modifying drug in patients with knee osteoarthritis? Journal of Rheumatology 29:1308-1320.

Chand, N.; Naz, S.; Khan, A.; Khan, S. and Khan, R. U. 2014 Performance traits and immune response of broiler chicks treated with zinc and ascorbic acid supplementation during cyclic heat stress. International Journal of Biometeorology 58:2153-2157. https://doi.org/10.1007/s00484-014-0815-7

Clark, D. M. 1991. Current concepts in the treatment of degenerative joint disease. Compendium on Continuing Education for the Practicing Veterinarian 13:1439-1446.

De Mattei. M.; Pellati, A.; Passelo, M.; Terlizzi, F. D. E.; Massari, L.; Gemmati, D. and Caruso, A. 2002. High doses of glucosamine- 
$\mathrm{HCl}$ have detrimental effects on bovine articular cartilage explants cultured in vitro. Osteoarthritis Cartilage 10:816-825. https://doi. org/10.1053/joca.2002.0834

Eleotério, R. B.; Borges, A. P. B.; Pontes, K. C. S.; Fernandes, N. A.; Soares, P. F.; Silva, M. B.; Martins, N. J. S. and Machado, J. P. 2012. Glucosamine and chondroitin sulfate in the repair of osteochondral defects in dogs: clinical-radiographic analysis. Revista Ceres 59:587-596. https://doi.org/10.1590/S0034-737X2012000500003

Fenton, J. I.; Chlebek-Brown, K. A.; Peters, T. L.; Caron, J. P. and Orth, M. W. 2000. The effects of glucosamine derivatives on equine articular cartilage degradation in explant culture. Osteoarthritis and Cartilage 8:444-451. https://doi.org/10.1053/joca.1999.0320

Ferreira, I. B.; Matos Junior, J. B.; Sgavioli, S.; Vicentini, T. I.; Morita, V. S. and Boleli, I. C. 2015. Vitamin C prevents the effects of high rearing temperatures on the quality of broiler thigh meat. Journal of Poultry Science 94:8141-8151. https://doi.org/10.3382/ps/pev058

Ghonim, A. I. A.; Awad, A. L.; Fattouh, M. H. A. and El-Shhat, A. M. 2009. Comparative study of ascorbic acid treatment methods on hatchability traits and growth performance of ducklings. Egyptian Poultry Science 29:1085-1099.

Gonçalves, G.; Melo, E. G.; Gomes, M. G.; Nunes, V. A. and Rezende, C. M. F. 2008. Effects of chondroitin sulfate and sodium hyaluronate on chondrocytes and extracellular matrix of articular cartilage in dogs with joint disease. Arquivo Brasileiro de Medicina Veterinária e Zootecnia 60:93-102.

Hanson, R. R.; Smalley, L. R.; Huff, G. K.; White, S. and Hamad, T. A. 1997. Oral treatment with a glucosamine-chondroitin sulfate compound for degenerative joint disease in horses: 25 cases. Equine Practice 19:16-22.

Jochemsen, P. and Jeurissen, S. H. 2002. The localization and uptake of in ovo injected soluble and particulate substances in the chicken. Journal of Poultry Science 81:1811-1817. https://doi.org/10.1093/ $\mathrm{ps} / 81.12 .1811$

Littell, R. C.; Stroup, W. W.; Milliken, G. A.; Wolfinger, R. D. and Schabenberger, O. 2006. SAS for mixed models. 2nd ed. SAS Publishing.

Melo, E. G.; Nunes, V. A.; Rezende, C. M. F.; Gomes, M. G.; Malm, C. and Gheller, V. A. 2008. Sulfato de condroitina e hialuronato de sódio no tratamento da doença articular degenerativa em cães. Estudo histológico da cartilagem articular e membrana sinovial. Arquivo Brasileiro de Medicina Veterinária e Zootecnia 60:83-92. https://doi.org/10.1590/S0102-09352008000100013

Mohammed, K. A.; El-Boghdady, A.; Soliman M. A. H.; Abd Agalil, M. A. and Abd Aleem, N. M. 2011. The effect of both preincubation dipping eggs in vitamin $\mathrm{C}$ and cooling eggs during incubation period on embryonic and hatchability parameters in two local chicken strains. Egypt Poultry Science 31:379-392.

Nowaczewski, S.; Kontecka, H. and Krystianiak, S. 2012. Effect of in ovo injection of vitamin $\mathrm{C}$ during incubation on hatchability of chickens and ducks. Folia Biológica 60:93-97.

Ohta, Y.; Kidd, M. T. and Ishibashi, T. 2001. Embryo growth and amino acid concentration profiles of broiler breeder eggs, embryos, and chicks after in ovo administration of amino acids. Journal of Poultry Science 80:1430-1436. https://doi.org/10.1093/ ps/80.10.1430
Reginster, J. Y.; Deroisy, R.; Rovati, L. C.; Lee, R. L.; Lejeune, E.; Bruyere, O.; Giacovelli, G.; Henrotin, Y.; Dacre, J. E. and Gossett, C. 2001. Long-term efects of glucosamine sulfate on osteoarthritis progression: a randomised, placebo-controlled clinical trial. Lancet 357:251-256. https://doi.org/10.1016/S0140 $-6736(00) 03610-2$

Robbins, K. R.; Norton, H. W. and Baker, D. H. 1979. Estimation of nutrient requirements from growth data. Journal of Nutrition 109:1710-1714. https://doi.org/10.1093/jn/109.10.1710

Santos, T. T.; Corzo, A.; Kidd, M. T.; McDaniel, C. D.; Torres Filho, R. A. and Araújo, L. F. 2010. Influence of in ovo inoculation with various nutrients and egg size on broiler performance. Journal of Applied Poultry Research 19:1-12. https://doi.org/10.3382/ japr.2009-00038

Sgavioli, S.; Borges, L. L.; Almeida, V. R.; Thimotheo, M.; Oliveira, J. A. and Boleli, I. C. 2013. Egg injection of ascorbic acid stimulates leucocytosis and cell proliferation in the bursa of Fabricius. International Journal Poultry Science 12:464-472. https://doi. org/10.3923/ijps.2013.464.472

Sgavioli, S.; Matos Júnior, J. B.; Borges, L. L.; Praes M. F. F. M.; Morita, V. S.; Zanirato, G. L.; Garcia, R. G. and Boleli, I. C. 2015. Effects of ascorbic acid injection in incubated eggs submitted to heat stress on incubation parameters and chick quality. Revista Brasileira de Ciência Avícola 17:181-189. https:// doi.org/10.1590/1516-635x1702181-190

Sgavioli, S.; Santos, E. T.; Borges, L. L.; Andrade-Garcia, G. M.; Castiblanco, D. M. C.; Almeida, V. R.; Garcia, R. G.; Shimano, A. C.; Nääs, I. A. and Baraldi-Artoni, S. M. 2017. Effect of the addition of glycosaminoglycans on bone and cartilaginous development of broiler chickens. Journal of Poultry Science 96:4017-4025. https://doi.org/10.3382/ps/pex228

Shim, M. Y. and Pesti, G. M. 2011. Effects of incubation temperature on the bone development of broilers. Journal of Poultry Science 90:1867-1877. https://doi.org/10.3382/ps.2010-01242

Silva, D. J. and Queiroz, A. C. 2002. Análise de alimentos: métodos químicos e biológicos. 3.ed. Universidade Federal de Viçosa, Viçosa, MG.

Simonaro, C. M.; D’Angelo, M.; He, X.; Eliyahu, E.; Shtraizent, N.; Haskins, M. E. and Schuchman, E. H. 2008. Mechanism of glycosaminoglycan-mediated bone and joint disease: implications for the mucopolysaccharidoses and other connective tissue diseases. The American Journal of Pathology 172:112-122. https://doi.org/10.2353/ajpath.2008.070564

Uni, Z. and Ferket, R. P. 2003. Enhancement of oviparous species by in ovo feeding. US Patent 6.592.878 B2. North Carolina State University, Raleigh.

Uni, Z. and Ferket, R. P. 2004. Methods for early nutrition and their potential. World's Poultry Science Journal 60:103-113. https://doi. org/10.1079/WPS20038

Vargas Junior, J. G.; Albino, L. F. T.; Rostagno, H. S.; Gomes, P. C.; Carvalho, D. C. O.; Cupertino, E. S.; Toledo, R. S. and Pinto, R. 2004. Níveis nutricionais de cálcio e de fósforo disponível para aves de reposição leves e semipesadas de 13 a 20 semanas de idade. Revista Brasileira de Zootecnia 33:1263-1273. https://doi. org/10.1590/S1516-35982004000500019 